\title{
Giant Cell Fibroma in Children: Report of Two Cases and Literature Review
}

\author{
Nikolaos G. Nikitakis', Dimitris Emmanouil², Michail P. Maroulakos ${ }^{3}$, Matina V. Angelopoulou² \\ ${ }^{1}$ Department of Oral Medicine and Pathology, Dental School, University of Athens, Greece. \\ ${ }^{2}$ Department of Pediatric Dentistry, Dental School, University of Athens, Greece. \\ ${ }^{3}$ Department of Orthodontics, Dental School, University of Athens, Greece.
}

\author{
Corresponding Author: \\ Matina V. Angelopoulou \\ 28 Kalamatas Str., Kifisia 14564, Athens \\ Greece \\ Phone: +30 6971896981 \\ E-mail: matinangelop@yahoo.gr
}

\section{ABSTRACT}

Background: Giant cell fibroma is a type of fibrous tumour of the oral mucosa which rarely affects children under the age of 10. The purpose of this paper was to contribute two clinically and histologically documented cases of giant cell fibroma in the free gingiva of a 7 and 6 year old boys.

Methods: Both nodules were presented in the mandibular anterior region. In the differential diagnosis several fibrous hyperplastic lesions were considered such as traumatic fibroma, papilloma, peripheral ossifying fibroma, peripheral odontogenic fibroma, giant cell fibroma and odontogenic hamartoma.

Results: The lesions were removed and the histological examination revealed fibrocollagenous connective tissue with the presence of stellate giant cells which confirmed the diagnosis of giant cell fibroma.

Conclusions: Dentists should be aware of the existence of giant cell fibroma in children, which must be included in the differential diagnosis of nodular lesions of the gingiva and adequately diagnosed and treated by removal and histopathological examination.

Keywords: fibroma; children; gingiva.

Accepted for publication: 27 February 2013

To cite this article:

Nikitakis NG, Emmanouil D, Maroulakos MP, Angelopoulou MV. Giant Cell Fibroma in Children: Report of Two Cases and Literature Review.

URL: http://www.ejomr.org/JOMR/archives/2013/1/e5/v4n1e5ht.pdf

doi: $10.5037 /$ jomr.2013.4105 


\section{INTRODUCTION}

The Giant cell fibroma (GCF) is a lesion of fibrous connective tissue origin, which was first described as a distinct entity by Weathers and Callihan in 1974 [1]. Its name alludes to the characteristic cells present within the fibrous stroma of the lesion. It represents approximately $2-5 \%$ of all fibrous lesions submitted for biopsy $[1-6,7]$ and $0.4-1 \%$ of total biopsies $[1-3,7]$ although greater percentages have also been reported (10.6\% and $2.7 \%$ respectively) [ 8$]$ ]. The lesion presents clinically as asymptomatic, sessile or peduculated nodule, with papillary surface and normal coloration $[1,3, \underline{4}, 6-10]$. It is usually less than $1 \mathrm{~cm}$ in diameter $[\underline{1}, \underline{3}, \underline{6}, \underline{,}, \underline{9}, \underline{11}, \underline{12}]$ and can be present for a long period of time $[\underline{7}, \underline{8}]$.

The histological features of the lesion include the presence of stellate shaped fibroblasts with delicate dendritic-like processes and one, two or multiple nuclei $[1-4, \underline{6}, 8-10,12-17]$. These cells are usually found just beneath the epithelium $[\underline{1}, \underline{6}, \underline{7}, 13,14,17]$. The stroma consists of fibrous connective tissue [1-3, $\underline{6}, \underline{8-10}, \underline{12}, \underline{15}, \underline{17}]$, quite collagenous, with a whorled pattern and variable numbers of spindle-shaped fibroblasts $[\underline{1}, \underline{3}, \underline{6}]$, while the overlying epithelium is usually thin with narrow and elongated rete pegs $[\underline{6}, \underline{10}, \underline{15}, \underline{17}]$.

GCF usually affects patients in the $2^{\text {nd }}$ and $3^{\text {rd }}$ decade of life $[\underline{1-3}, \underline{5}, \underline{7}, \underline{11}, \underline{17]}$ and only $4-17 \%$ of the GCF cases have been reported in children under the age of $10[\underline{1}, \underline{2}, \underline{8}]$.

The aim of this study was to present the case report of two boys 7 and 6 year-old respectively with GCF of the anterior mandibular gingiva and to review the current literature concerning the demographic, clinical

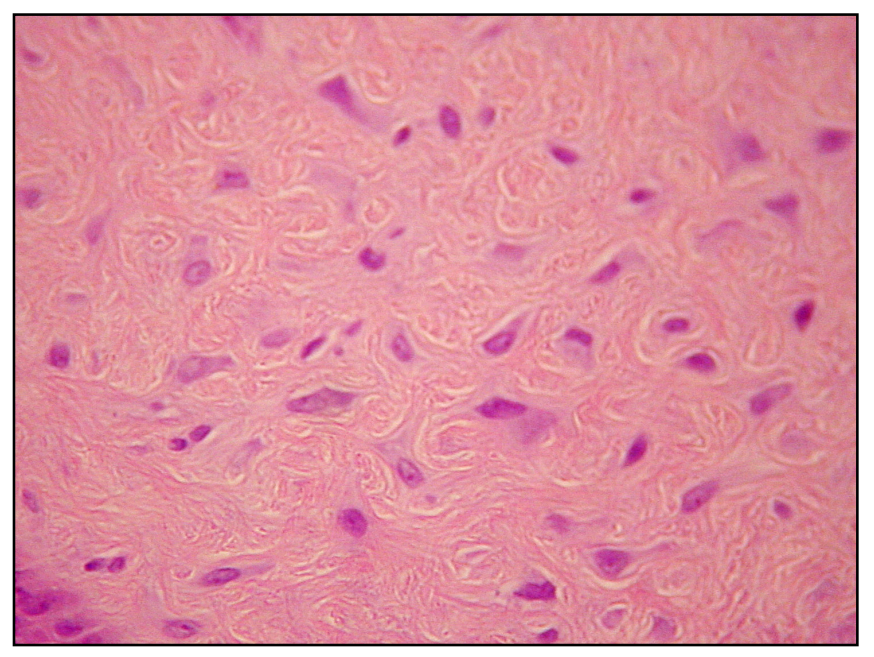

Figure 1. Multiple stellate cells with one or two nuclei and basophilic cytoplasm within a fibrous connective tissue stroma (Case report 1, hematoxylin and eosin stain, original magnification $\mathrm{x} 400$ ). and histopathological features of this uncommon lesion in children.

\section{CASE DESCRIPTION AND RESULTS Case report 1}

The patient, a 7 year-old Caucasian boy, was referred by a paediatric dentist for evaluation of a lesion on the free gingiva of the anterior mandible. The lesion was asymptomatic and had been present for 3 years remaining stable in size, shape and colour. The permanent right lateral incisor had uneventfully erupted 6 months ago. Medical history was uneventful except of the presence of allergic rhinitis treated with anthistamine nasal spray. On oral clinical examination, a penduculated soft tissue nodule measuring $0.4 \times 0.3 \mathrm{~mm}$ was noticed on the free gingiva distal to the permanent lower lateral incisor. The lesion was non-haemorrhagic, of firm consistency, covered by intact white mucosa. The rest of the oral mucosa was normal and the child's oral hygiene was satisfactory.

Based on the clinical appearance and the lesion's history, the differential diagnosis included primarily reactive and benign neoplastic lesions, such as traumatic fibroma, peripheral ossifying fibroma, peripheral odontogenic fibroma, giant cell fibroma and odontogenic hamartoma. The lesion was excised under local anaesthesia and haemorrhage control was achieved without need for suture application.

Microscopic examination of the excised specimen revealed fibrocollagenous connective tissue with dispersed spindle-shaped fibroblasts and bigger stellate cells with 1 or 2 nuclei (Figure 1). The overlying squamous epithelium was keratinized forming thin, elongated projections (Figure 2). The diagnosis of

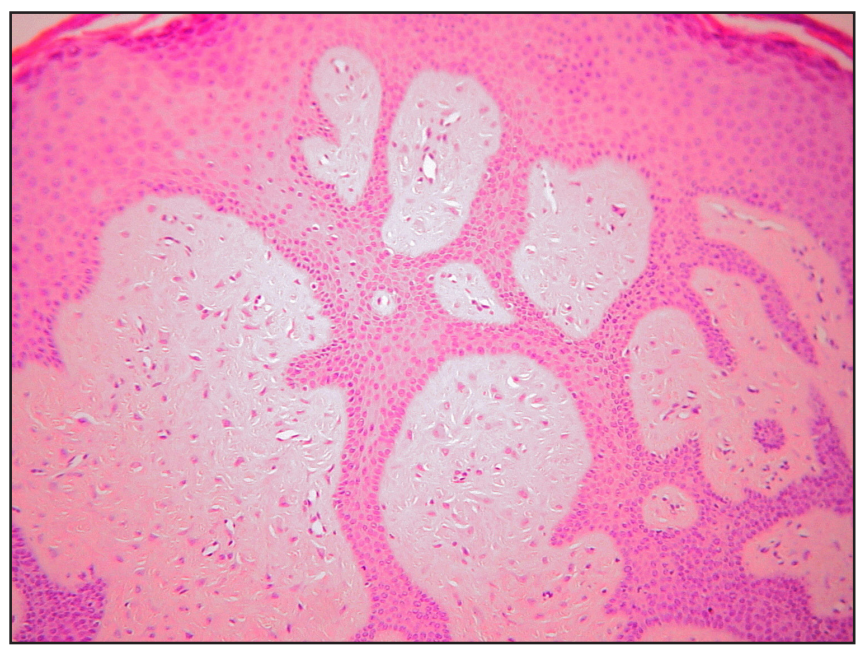

Figure 2. Stellate giant cells in close proximity to the overlying epithelium, which forms elongated rete pegs (Case report 1, hematoxylin and eosin stain, original magnification x100). 
giant cell fibroma was rendered. No postoperative complications were noted and the healing process was good. The patient has been followed for 2 years since then without recurrence of the lesion.

\section{Case report 2}

A 6 year-old Caucasian boy was referred for dental restoration. Clinical examination revealed the presence of a hyperplastic lesion in the interproximal area between the left deciduous mandibular lateral incisor and canine; the lesion was extending both buccally $(3 \times 2 \mathrm{~mm})$ and lingually $(4 \times 3 \mathrm{~mm})$ (Figure $3 \mathrm{~A}, \mathrm{~B})$. The lesion was asymptomatic and non-hemorrhagic and appeared pedunculated, papillary surfaced, white and firm. The rest of the oral mucosa was normal. Deciduous, lower central incisors had exfoliated and permanent lower first molars had erupted without any complications. The medical history revealed moderate asthma episodes, controlled by medication, and allergy to amoxicillin.

Based on clinical appearance differential diagnosis included traumatic fibroma, papilloma, peripheral ossifying fibroma, peripheral odontogenic fibroma and giant cell fibroma. The lesion was excised with electrocautery under local anaesthesia.

Microscopic examination of the excised lesion revealed connective tissue with thick collagenous fibres and presence of dispersed stellate giant cells with sizeable, vesicular nuclei, mainly in a subepithelial localization. The epithelium was keratinized squamous stratified forming thin, elongated projections (Figure 4A, B). The pathological findings were consistent with giant cell fibroma. Healing process was normal without any complications or evidence of recurrence of the lesion 4 years after the excision.

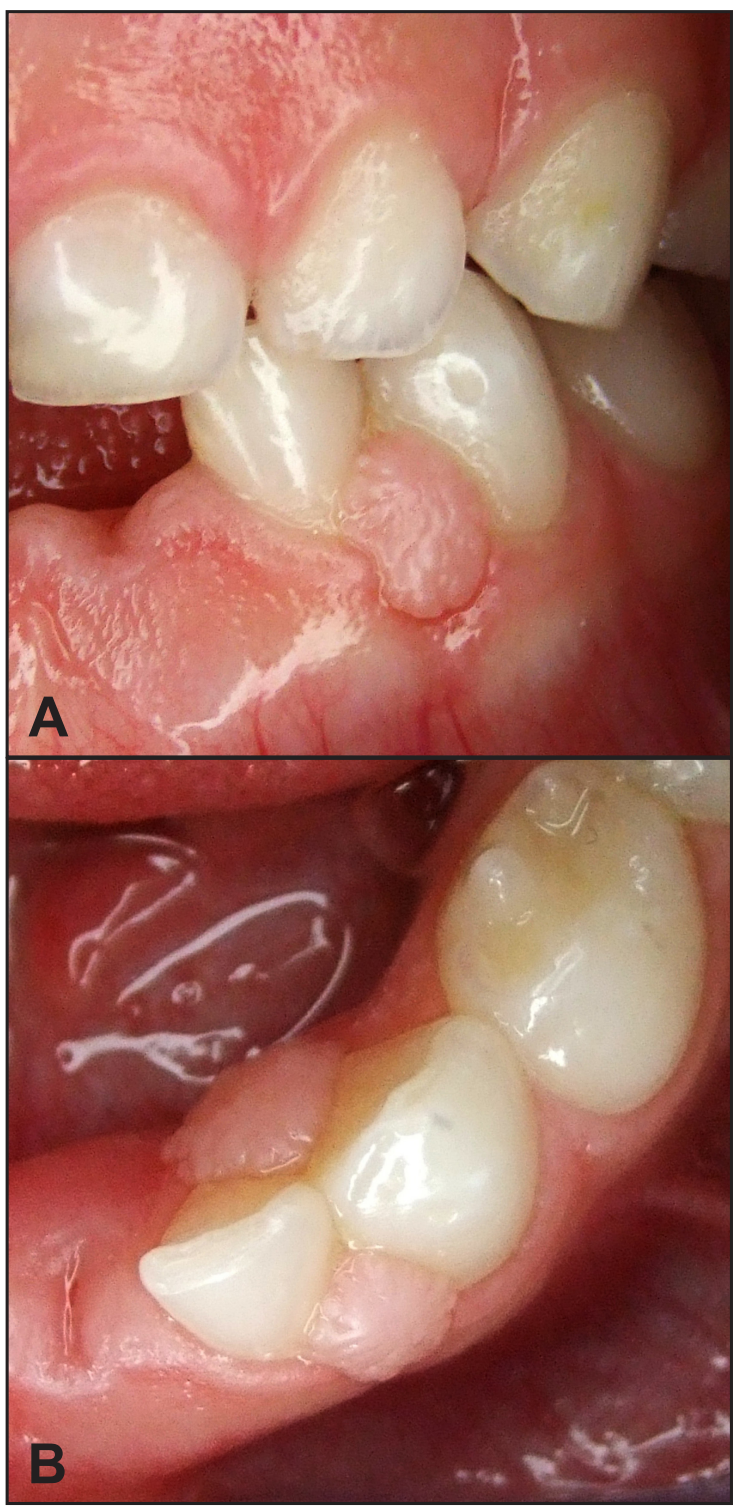

Figure 3. $\mathrm{A}=$ buccal view and $\mathrm{B}=$ occlusal view of the nodular lesion of Case report 2 in the interproximal area between the deciduous lateral incisor and canine.

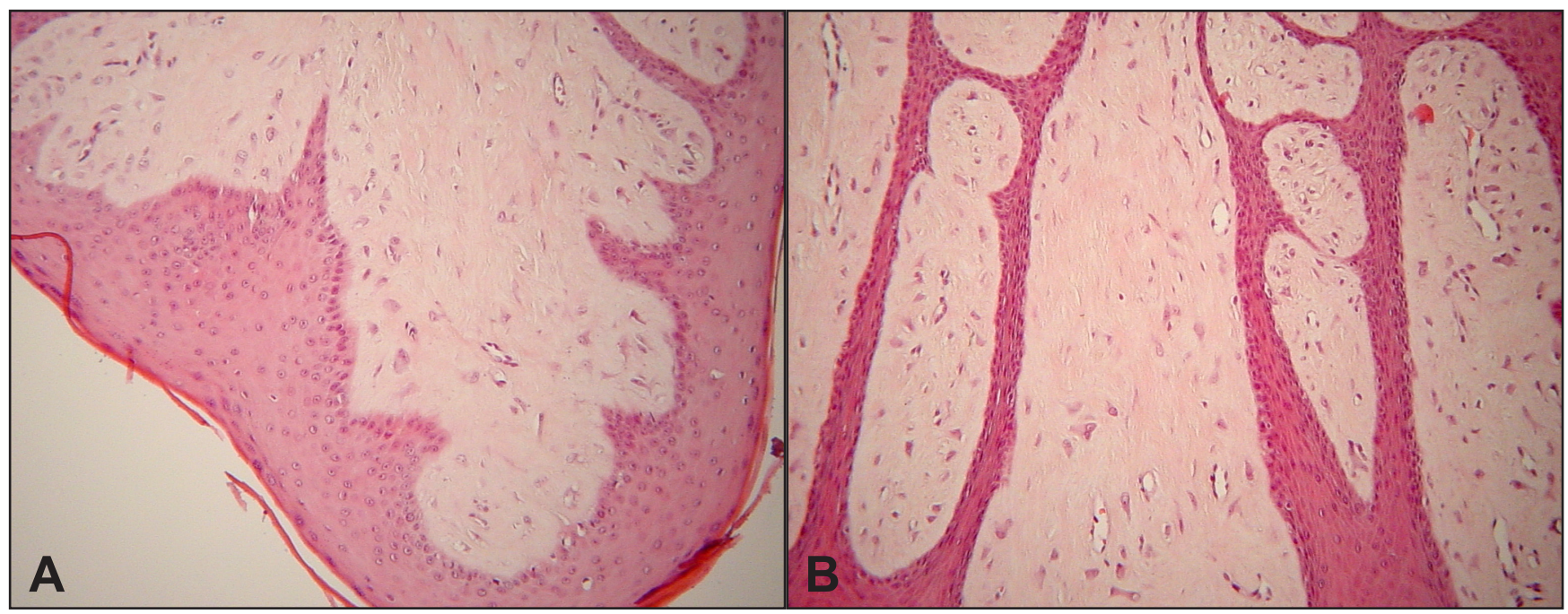

Figure 4. $\mathrm{A}$ and $\mathrm{B}=$ photomicrographs showing multiple stellate cells dispersed in a fibrous connective tissue stroma; elongated epithelial rete pegs are also discerned (Case report 2, hematoxylin and eosin stain, original magnification $\mathrm{x} 400$ ). 


\section{DISCUSSION}

GCF is most commonly reported $(90-97 \%)$ in Caucasians; $[\underline{1}, \underline{3}, \underline{7}, \underline{8}]$ our review of the four largest published series of GCF revealed that Caucasians were affected in 597/625 (95\%) of cases with available race information (Table 1). Most cases reported in the literature regarding children under the age of 10 were Caucasian, as well as both of the cases reported in the current article (Table 2) [7, 18-20].

Based on the literature, GCF usually affects patients in the 2nd and 3rd decades of life $[1-3,5, \underline{5}, 11,17]$ with approximately $60 \%$ of cases found in the first three decades of life $[1-6,9,10, \underline{11}, \underline{21}]$. However, a higher incidence in 3rd to 5th decades has also been reported $[\underline{8}, \underline{15}]$. In our review,
$122 / 771(15.8 \%)$ and $181 / 771(23.5 \%)$ of patients were in the first and second decade of life, respectively (Table 1). Overall, GCF is an uncommon lesion among young children. Only 4 to $17 \%$ of GCFs have being found in the 1st decade, similar to the age of our cases $[\underline{1}, \underline{2}, \underline{8}, \underline{15}, \underline{17}, \underline{18}]$. The youngest age of GCF described in children is 18 months old [24].

There is no significant sex predilection $[\underline{2}, \underline{5}, \underline{9}, \underline{15}]$ despite the fact that some studies have suggested a slight female preference (1.3 - 1.5:1 female to male ratio) $[\underline{1}, \underline{3}, \underline{4}$, 6-10]. However, a slight male predilection has also been reported (1:1.3 female to male ratio) [17]. A female predilection $(446 / 791,56 \%)$ was also apparent in our literature review (Table 1) $[\underline{1}, \underline{3}, \underline{4}, \underline{6}, \underline{7}, \underline{9}, \underline{31}]$ and in most cases reported in the literature regarding children under the age of 10 (Table 2) [17, 18,20,22-24]; however, both our patients were male.

Table 1. Summary of the demographic data and location distribution of large published series of giant cell fibromas in the literature

\begin{tabular}{|c|c|c|c|c|c|}
\hline Authors & $\begin{array}{l}\text { Weathers et al. } \\
\text { (1974) [1] }\end{array}$ & Houston (1982) []] & Bakos (1992) [ㅁ] & $\begin{array}{l}\text { Magnusson et al. } \\
\text { (1995) [2] }\end{array}$ & Total \\
\hline $\mathbf{N}$ & 108 & 464 & 116 & 103 & 791 \\
\hline \multicolumn{6}{|l|}{ Sex } \\
\hline Male & $49(45 \%)$ & $195(42 \%)$ & $46(40 \%)$ & $55(53 \%)$ & $345(44 \%)$ \\
\hline Female & $59(55 \%)$ & $269(58 \%)$ & $70(60 \%)$ & $48(47 \%)$ & $446(56 \%)$ \\
\hline \multicolumn{6}{|l|}{ Race } \\
\hline Caucasian & $69(64 \%)$ & $415(89.4 \%)$ & $113(97 \%)$ & - & $597(76.5 \%)$ \\
\hline Black & $5(5 \%)$ & $19(4.1 \%)$ & - & - & $24(3 \%)$ \\
\hline Other & - & $2(0.5 \%)$ & $3(3 \%)$ & - & $5(0.5 \%)$ \\
\hline Not specified & $34(31 \%)$ & $28(6 \%)$ & - & 103 & $165(20 \%)$ \\
\hline \multicolumn{6}{|l|}{ Age } \\
\hline $0-10$ & $19(18 \%)$ & $81(17.5 \%)$ & $6(5 \%)$ & $16(15.5 \%)$ & $122(15.4 \%)$ \\
\hline $10-20$ & $26(24 \%)$ & $114(24.6 \%)$ & $7(6 \%)$ & $34(33 \%)$ & $181(22.9 \%)$ \\
\hline $20-30$ & $21(19 \%)$ & $74(15.9 \%)$ & $15(13 \%)$ & $15(14.6 \%)$ & $125(15.8 \%)$ \\
\hline $30-40$ & $8(7 \%)$ & $59(12.7 \%)$ & $25(22 \%)$ & $13(12.7 \%)$ & $105(13.3 \%)$ \\
\hline $40-50$ & $18(17 \%)$ & $47(10.1 \%)$ & $24(21 \%)$ & $8(7.7 \%)$ & $97(12.3 \%)$ \\
\hline $50-60$ & $6(6 \%)$ & $40(8.6 \%)$ & $13(11 \%)$ & $11(10.7 \%)$ & $70(8.8 \%)$ \\
\hline $60-70$ & $8(7 \%)$ & $21(4.5 \%)$ & $20(17 \%)$ & $3(2.9 \%)$ & $52(6.6 \%)$ \\
\hline $70-80$ & $2(2 \%)$ & $8(1.7 \%)$ & $6(5 \%)$ & $3(2.9 \%)$ & $19(2.4 \%)$ \\
\hline Not specified & - & $20(4.4 \%)$ & - & - & $20(2.5 \%)$ \\
\hline \multicolumn{6}{|l|}{ Location } \\
\hline Gingiva & $48(45 \%)$ & 227 (48.9\%) & $32(29 \%)$ & $55(53.4 \%)$ & $362(45.8 \%)$ \\
\hline Maxilla & $13(12 \%)$ & $84(18.1 \%)$ & - & $17(16.6 \%)$ & $114(34 \%)$ \\
\hline Mandible & $35(33 \%)$ & $143(30.8 \%)$ & - & $38(36.8 \%)$ & $216(65 \%)$ \\
\hline Buccal mucosa & $16(15 \%)$ & $27(5.8 \%)$ & $23(20 \%)$ & $12(11.7 \%)$ & $78(9.9 \%)$ \\
\hline Palate & $16(15 \%)$ & $86(18.5 \%)$ & $16(13 \%)$ & $4(3.9 \%)$ & $122(15.4 \%)$ \\
\hline Tongue & $18(16 \%)$ & $102(22 \%)$ & $22(19 \%)$ & $24(23.3 \%)$ & $166(21 \%)$ \\
\hline Lips & $2(1.5 \%)$ & $12(2.5 \%)$ & $5(4 \%)$ & $1(0.9 \%)$ & $20(2.5 \%)$ \\
\hline Floor of mouth & $1(1 \%)$ & $1(0.3 \%)$ & $2(2 \%)$ & - & $4(0.5 \%)$ \\
\hline Not specified & $4(4 \%)$ & $7(1.5 \%)$ & - & $7(6.8 \%)$ & $18(2.3 \%)$ \\
\hline Other & $3(2.5 \%)$ & $2(0.5 \%)$ & $16(13 \%)$ & - & $21(2.6 \%)$ \\
\hline
\end{tabular}

$\mathrm{N}=$ number of number of patients. 
Table 2. Summary of the demographic data and location distribution of published in the literature giant cell fibromas in children under 12 years old

\begin{tabular}{|c|c|c|c|c|c|c|c|c|c|c|c|}
\hline & 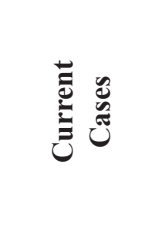 & 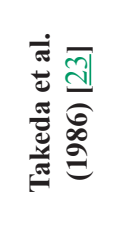 & 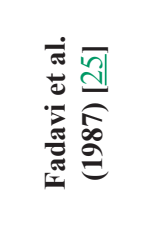 & 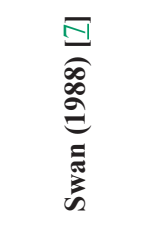 & 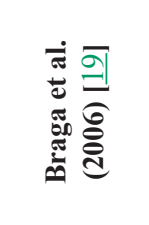 & 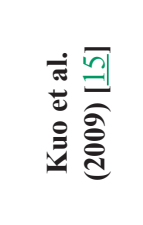 & 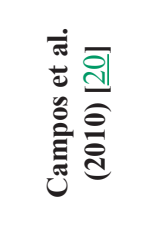 & 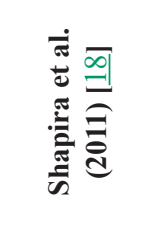 & 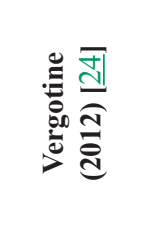 & 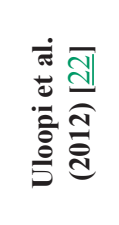 & 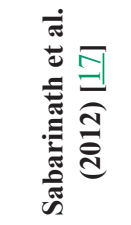 \\
\hline Sex & Males & Female & Male & Female & Male & Male & Female & Female & Female & Female & Female \\
\hline $\begin{array}{c}\text { Race/ } \\
\text { Nationality }\end{array}$ & Caucasian & Asian & - & Caucasian & Caucasian & Asian & Caucasian & Caucasian & $\begin{array}{l}\text { African- } \\
\text { American }\end{array}$ & Indian & Indian \\
\hline $\begin{array}{c}\text { Age } \\
\text { (years) }\end{array}$ & 6 and 7 & 3 & 11 & 6 & 3 & 7 & 11 & 6 & 1,5 & 12 & 9 \\
\hline Location & $\begin{array}{l}\text { Mandibular } \\
\text { gingiva }\end{array}$ & $\begin{array}{c}\text { Oral } \\
\text { mucosa }\end{array}$ & $\begin{array}{c}\text { Maxillary } \\
\text { gingiva }\end{array}$ & $\begin{array}{c}\text { Maxillary } \\
\text { gingiva }\end{array}$ & $\begin{array}{c}\text { Maxillary } \\
\text { gingiva }\end{array}$ & $\begin{array}{c}\text { Maxillary } \\
\text { gingiva }\end{array}$ & $\begin{array}{c}\text { Maxillary } \\
\text { gingiva }\end{array}$ & Tongue & $\begin{array}{c}\text { Maxillary } \\
\text { gingiva }\end{array}$ & Tongue & $\begin{array}{c}\text { Maxillary } \\
\text { gingiva }\end{array}$ \\
\hline
\end{tabular}

The literature review confirmed the gingiva as the most commonly affected location (362/773, 46.8\%) among cases with specified site, with a predilection for the mandible (2:1 mandible to maxilla ratio) $[\underline{1-4}, \underline{6}, \underline{8}, \underline{9}, \underline{12}]$. The lesions' localization in both cases presented here was the mandibular gingiva which is in accordance to the gingiva predilection reported in the literature $[1-12,17]$; however the maxillary gingiva has been reported as the most common location in children under the age of 10 (Table 2) $[\underline{7}, \underline{15}, \underline{17}, \underline{19}, \underline{20}, \underline{24}, \underline{25}]$. Other affected locations by descending order of frequency are the tongue, palate, buccal mucosa, lips and floor of the mouth $[\underline{1-3}, \underline{7}, \underline{8}, \underline{15}, \underline{17}]$ (Table 1).

The differential diagnosis of a firm, soft tissue nodule in the gingiva of a child may include irritation fibroma, papilloma, peripheral ossifying fibroma, focal fibrous hyperplasia, peripheral odontogenic fibroma and odontogenic hamartoma. Irritation fibroma usually occurs at an older age, the buccal mucosa being the most common location $[1,2,2, \underline{5}, \underline{11}, \underline{15}]$. It is one of the commonest oral lesions representing approximately $25 \%$ of total biopsies [8]. Irritation fibroma has a distinct female predilection $[\underline{1}, 9]$, and usually is larger than $1 \mathrm{~cm}$ [11]. In addition, the frequent pebbly or papillary surface and the potential pedunculated appearance of GCF are not features of irritation fibroma. Peripheral ossifying fibroma is characterized by calcified regions, which may be apparent radiographically. It is found exclusively in the gingiva, possibly causing superficial resorption of the alveolar ridge [6], whereas GCF can also occur in different areas of the oral mucosa [9]. Focal fibrous hyperplasia (fibrous epulis) has similar clinical appearance; however the absence of giant cells which are typical histopathological finding in GCF can set the diagnosis [18]. Peripheral odontogenic fibroma and odontogenic hamartoma are rare entities typified by the presence of odontogenic epithelium at the microscopic level [12].
In cases of GCFs with a prominent papillary surface, as in our second case, the differential diagnosis may also include papillomas, which present unique histopathological findings $[\underline{1}, \underline{6}, \underline{7}, \underline{\underline{9}}]$.

Retrocuspid papillae is a developmental lesion $[\underline{6}, \underline{9}, 13]$ presenting as a small, pink nodule always found lingual to the mandibular canine. The lesions, which are frequently bilateral, present in childhood and regress with age $[\underline{6}, \underline{9}, \underline{13}]$. Retrocuspid papilla has identical histological features with those of GCF and is distinguished on the grounds of their distinct location.

The reactive, hamartomatous or neoplastic nature of GCF is debated. Some authors support the possible reactive or hamartomatous origin of the lesion as opposed to a true neoplastic nature $[2,5]$. Moreover, the occasional presence of inflammatory cells supports the idea that GCF might develop as a response to trauma or recurrent chronic inflammation, although irritation and inflammatory changes may occur secondary to the development of the lesion $[\underline{5}, \underline{9}, 13,19]$. On the other hand, it has been proposed that GCF, in contrast to reactive fibrous lesions, may not be attributed to chronic irritation [6]. In addition, pyogenic granuloma has been considered as another probable origin of GCF. The common location of both tumours on the gingival and the increased vascularity of GCF stroma supported the notion that GCF may be a mature form of pyogenic granuloma and the giant cells derive from the endothelium $[\underline{5}, \underline{11}]$. Nonetheless, giant cells were negative for endothelial markers $[\underline{8}, \underline{10}, 12]$.

The origin of the giant cells is also controversial. The most accepted theory supports a fibroblastic origin of giant cells $[\underline{1}, \underline{2}, \underline{5}, \underline{9}, \underline{10}, \underline{11-13}]$. However, these giant cells contain more microfibrils, a distinctive appearance that may reflect a functional response to the requirement for higher protein and collagen formation $[\underline{5}, \underline{11}]$. Some researchers argue that the giant cells might be multipotential mesenchymal cells with 
myofibroblastic differentiation [4, $\underline{5}$, but myofibroblastic origin is unlikely due to the negative alpha-smooth muscle actin reaction $[10,12]$.

As far as the treatment of GCF is concerned, a conservative surgical excision is usually curative $[\underline{3}, \underline{6}, \underline{8}, \underline{\underline{ }}]$ and is the treatment of choice in most cases reported in the literature regarding children under the age of $10[\underline{7}, \underline{18}, \underline{20}, \underline{22}, \underline{24}, \underline{25}]$. Electrosurgery is another option and has been used in paediatric dentistry in various procedures such as frenectomy, incision of hyperplastic gingiva, biopsies and pulpotomy $[19,26]$. Electrosurgery's main advantage is the direct tissue haemostasis without need for sutures $[\underline{19}, \underline{26}]$. In addition there can be access to areas difficult to reach and reduction of chair time, factors extremely valuable in paediatric dentistry [26]. Laser therapy has been suggested as an alternative approach with many advantages especially in the dental treatment of children $[\underline{27}, \underline{28}]$. Concerning the excision of soft tissue lesions, $\mathrm{CO} 2$ and $\mathrm{Nd}$ :YAG laser have been suggested for the excision of fibromas with various advantages such as direct haemostasis and disinfection of the surgical field, minimal postoperative pain and inflammation, elimination of sutures and acceleration of the healing process [28]; however, they lead to vaporization of the lesion and do not allow histopatholigocal analysis of the tissue [28]. Diode and erbium lasers are also optional in the treatment of soft tissues $[28,29]$ indicated for the excision of lesions while permitting histopathological analysis.

Recurrences have been reported only in solitary cases $[\underline{3}, \underline{6}, \underline{8}, \underline{15}]$. However, recall visits are necessary to ensure the absence of recurrence [19]. If the lesion is left untreated it may continue to proliferate $[1,9]$ but its benign nature certifies limited growth potential $[18,21]$. Moreover, GCF in contrast to other gingival lesions, such as the peripheral ossifying fibroma, has never been reported to cause migration of teeth or inter-dental resorption of the alveolar ridge [ $[6]$.

\section{CONCLUSIONS}

Giant cell fibroma is an uncommon lesion among young children. However, dentists should be aware of the existence of giant cell fibroma in children, which must be included in the differential diagnosis of nodular lesions of the gingiva along with irritation fibroma, papilloma, peripheral ossifying fibroma, peripheral odontogenic fibroma and odontogenic hamartoma. Following adequate diagnosis, lesions can be removed either with conservative surgical excision, electrosurgery or soft tissue laser and should be sent for histopathological examination.

\section{ACKNOWLEDGMENTS AND DISCLOSURE STATEMENTS}

The authors report no conflicts of interest related to this study.

Case 2 was a patient of the postgraduate clinic of Paediatric Dentistry, Dental School, University of Athens.

\section{REFERENCES}

1. Weathers DR, Callihan MD. Giant-cell fibroma. Oral Surg Oral Med Oral Pathol. 1974 Mar;37(3):374-84. [Medline: 4521457] [doi: 10.1016/0030-4220(74)90110-8]

2. Magnusson BC, Rasmusson LG. The giant cell fibroma. A review of 103 cases with immunohistochemical findings. Acta Odontol Scand. 1995 Oct;53(5):293-6. [Medline: 8553805] [doi: 10.3109/00016359509005990]

3. Houston GD. The giant cell fibroma. A review of 464 cases. Oral Surg Oral Med Oral Pathol. 1982 Jun;53(6):582-7. [Medline: 6954437] [doi: 10.1016/0030-4220(82)90344-9]

4. Savage NW, Monsour PA. Oral fibrous hyperplasias and the giant cell fibroma. Aust Dent J. 1985 Dec;30(6):405-9. [Medline: 3868396] [doi: 10.1111/j.1834-7819.1985.tb02549.x]

5. Reibel J. Oral fibrous hyperplasias containing stellate and multinucleated cells. Scand J Dent Res. 1982 Jun;90(3):217-26. [Medline: 6955934]

6. Neville BW, Damm DD, Allen CM, Bouquot JE. Soft Tissue Tumors. In: Dollan J, ed. Oral and Maxillofacial Pathology. 3rd ed. St.Louis: Saunders Elsevier;2009. p. 509-10.

7. Swan RH. Giant cell fibroma. A case presentation and review. J Periodontol. 1988 May;59(5):338-40. [Medline: 3290432] [doi: 10.1902/jop.1988.59.5.338]

8. Bakos LH. The giant cell fibroma: a review of 116 cases. Ann Dent. 1992 Summer;51(1):32-5. [Medline: 1378713]

9. Lukes SM, Kuhnert J, Mangels MA. Identification of a giant cell fibroma. J Dent Hyg. 2005 Summer;79(3):9. [Medline: 16197774]

10. Campos E, Gomez RS. Immunocytochemical study of giant cell fibroma. Braz Dent J. 1999;10(2):89-92. [Medline: 10863394]

11. Weathers DR, Campbell WG. Ultrastructure of the giant-cell fibroma of the oral mucosa. Oral Surg Oral Med Oral Pathol. 1974 Oct;38(4):550-61. [Medline: 4528844] [doi: 10.1016/0030-4220(74)90086-3] 
12. Odell EW, Lock C, Lombardi TL. Phenotypic characterisation of stellate and giant cells in giant cell fibroma by immunocytochemistry. J Oral Pathol Med. 1994 Jul;23(6):284-7. [Medline: 7523665] [doi: 10.1111/j.1600-0714.1994.tb00061.x]

13. Regezi JA, Courtney RM, Kerr DA. Fibrous lesions of the skin and mucous membranes which contain stellate and multinucleated cells. Oral Surg Oral Med Oral Pathol. 1975 Apr;39(4):605-14. [Medline: 1054468] [doi: 10.1016/0030-4220(75)90202-9]

14. Mighell AJ, Robinson PA, Hume WJ. PCNA and Ki-67 immunoreactivity in multinucleated cells of giant cell fibroma and peripheral giant cell granuloma. J Oral Pathol Med. 1996 May;25(5):193-9. [Medline: 8835814] [doi: 10.1111/j.1600-0714.1996.tb01371.x]

15. Kuo RC, Wang YP, Chen HM, Sun A, Liu BY, Kuo YS. Clinicopathological study of oral giant cell fibromas. J Formos Med Assoc. 2009 Sep;108(9):725-9. [Medline: 19773211] [doi: 10.1016/S0929-6646(09)60396-X]

16. Santos PP, Nonaka CF, Pinto LP, de Souza LB. Immunohistochemical expression of mast cell tryptase in giant cell fibroma and inflammatory fibrous hyperplasia of the oral mucosa. Arch Oral Biol. 2011 Mar;56(3):231-7. [Medline: 21035108] [doi: 10.1016/j.archoralbio.2010.09.020]

17. Sabarinath B, Sivaramakrishnan M, Sivapathasundharam B. Giant cell fibroma: A clinicopathological study. J Oral Maxillofac Pathol. 2012 Sep;16(3):359-62. [Medline: 23248467] [doi: 10.4103/0973-029X.102485] [FREE Full Text]

18. Shapira M, Akrish S. A 6-year-old girl with a lesion on the tongue. Giant cell fibroma of tongue. Pediatr Ann. 2011 Feb;40(2):71-4. [Medline: 21323202] [doi: 10.3928/00904481-20110117-05]

19. Braga MM, Carvalho AL, Vasconcelos MC, Braz-Silva PH, Pinheiro SL. Giant cell fibroma: a case report. J Clin Pediatr Dent. 2006 Spring;30(3):261-4. [Medline: 16683677]

20. Campos MS, Domaneschi C, Nunes FD, Weinfeld I. Giant cell fibroma of the maxillary gingiva in children: a case report. J Dent Child (Chic). 2010 Sep-Dec;77(3):174-6. [Medline: 22044471]

21. McGuff HS, Alderson GL, Cale Jones A, Keller TA. Oral and maxillofacial pathology case of the month. Giant cell fibroma. Tex Dent J. 2005 Jul;122(7):688-9, 692. [Medline: 16152898]

22. Uloopi KS, Vinay C, Deepika A, Sekhar RC, Raghu D, Ramesh T. Pediatric giant cell fibroma: an unusual case report. Pediatr Dent. 2012 Nov-Dec;34(7):503-5. [Medline: 23265171]

23. Takeda Y, Kaneko R, Suzuki A, Niitsu J. Giant cell fibroma of the oral mucosa. Report of a case with ultrastructural study. Acta Pathol Jpn. 1986 Oct;36(10):1571-6. [Medline: $\underline{3799191]}$

24. Vergotine RJ. A giant cell fibroma and focal fibrous hyperplasia in a young child: a case report. Case Rep Dent. 2012. [Medline: 22701188] [doi: 10.1155/2012/370242] [ FREE Full Text]

25. Fadavi S, Punwani I. Oral fibromas in children: reports of two cases. ASDC J Dent Child. 1987 Mar-Apr;54(2):126-8. [Medline: 3470329]

26. Anderman II. Indications for use of electrosurgery in pedodontics. Dent Clin North Am. 1982 Oct;26(4):711-28. [Medline: $\underline{6216127]}$

27. Genovese MD, Olivi G. Laser in paediatric dentistry: patient acceptance of hard and soft tissue therapy. Eur J Paediatr Dent. 2008 Mar;9(1):13-7. [Medline: 18380525]

28. Boj JR, Poirier C, Hernandez M, Espassa E, Espanya A. Review: laser soft tissue treatments for paediatric dental patients. Eur Arch Paediatr Dent. 2011 Apr;12(2):100-5. [Medline: 21473842] [doi: 10.1007/BF03262788]

29. Kotlow LA. Lasers in pediatric dentistry. Dent Clin North Am. 2004 Oct;48(4):889-922. [Medline: 15464557] [doi: 10.1016/j.cden.2004.05.005]

\footnotetext{
To cite this article: Literature Review.

J Oral Maxillofac Res 2013;4(1):eX

URL: http://www.ejomr.org/JOMR/archives/2013/1/e5/v4n1e5ht.pdf

doi: $10.5037 /$ jomr.2013.4105
}

Nikitakis NG, Emmanouil D, Maroulakos MP, Angelopoulou MV. Giant Cell Fibroma in Children: Report of Two Cases and

Copyright (C) Nikitakis NG, Emmanouil D, Maroulakos MP, Angelopoulou MV. Accepted for publication in the JOURNAL OF ORAL \& MAXILLOFACIAL RESEARCH (http://www.ejomr.org), 27 February 2013.

This is an open-access article, first published in the JOURNAL OF ORAL \& MAXILLOFACIAL RESEARCH, distributed under the terms of the Creative Commons Attribution-Noncommercial-No Derivative Works 3.0 Unported License, which permits unrestricted non-commercial use, distribution, and reproduction in any medium, provided the original work and is properly cited. The copyright, license information and link to the original publication on (http://www.ejomr.org) must be included. 